\title{
ТЕОРЕТИЧЕСКАЯ МОДЕЛЬ НАКОПЛЕНИЯ УГЛЕВОДОРОДОВ В КУПОЛЕ С УЧЁТОМ ГИДРАТООБРАЗОВАНИЯ, ЛИМИТИРУЮЩЕГОСЯ ТЕПЛООБМЕНОМ
}

\author{
Кильдибаева Светлана Рустамовна', \\ freya.13@mail.ru \\ Гималтдинов Ильяс Кадирович², \\ iljas_g@mail.ru \\ ' Стерлитамакский филиал Башкирского государственного университета, \\ Россия, 453103, г. Стерлитамак, пр. Ленина, 49. \\ 2 Уфимский государственный нефтяной технический университет, \\ Россия, 450062, г. Уфа, ул. Космонавтов, 1.
}

\begin{abstract}
Актуальность исследования связана с увеличением масштабов добычи углеводородов в шельфовой зоне Мирового океана и сопутствующими рисками аварийных разливов углеводородов. В качестве одного из способов ликвидации последствий глубоководных утечек предлагается установка купола над местом утечки. При ликвидации разлива нефти на нефтедобывающей платформе Deepwater Horizon была предпринята попытка установки устройства в виде купола, но гидраты, накопленные внутри купола, придавали конструкции плавучесть, вследствие чего купол всплывал и не мог быть зафиксирован. В связи с этим необходимо исследовать процесс гидратообразования и исключить его негативное влияние на работу купола. Для описания гидратообразования на поверхности пузырьков метана предложена предельная схема, согласно которой гидратообразование лимитируется теплообменом. В более ранних работах было рассмотрено накопление углеводородов с учётом гидратообразования, лимитируемого диффузией, что является другим предельным случаем описания гидратообразования. Исследуется математическая модель работы купола. В устройстве предусмотрены трубки для откачки накопленных углеводородов, это позволит избежать проблем с всплытием купола из-за накопления газа и гидрата.

Цель: исследовать особенности накопления углеводородов (нефти, газа, гидрата) в куполе для случая, когда гидратообразование лимитируется теплообменом с окружающей средой.

Объект: струя углеводородов, состоящая из воды, капель нефти, пузырьков газа и композитных пузырьков, которая попадая в купол, приводит к накоплению углеводородов в нём. Теплофизические характеристики окружающей среды соответствуют условиям стабильного существования гидрата.

Методы. Построена математическая модель накопления углеводородов в куполе. Для описания процессов тепломассопереноса использована система уравнений, включающая законы сохранения масс для компонентов, поступающих из струи (газ, нефть и гидрат), уравнения сохранения энергии для слоев газа и нефти, а также вспомогательные уравнения для расчетов тепловых потоков.

Результаты. Рассмотрен процесс накопления углеводородов в куполе в случае, когда гидратообразование на поверхности пузырьков метана лимитируется теплообменом. Когда плотность композитных пузырьков больше плотности нефти, слой гидрата (образованного композитными пузырьками) накапливается между слоями нефти и воды, в случае, когда плотность пузырька меньше плотности нефти, слой гидрата (образованного композитными пузырьками) накапливается между слоями газа и нефти. Определены температурные поля для углеводородов, накопленных внутри купола. С течением времени температуры слоев газа и нефти стремятся к температуре поступающих из струи нефти и газа.
\end{abstract}

\section{Ключевые слова:}

Купол, разлив углеводородов, шельф, нефть, гидрат, гидратообразование.

\section{Введение}

Исследование новых способов добычи, разведки и оценки запасов природных ресурсов носит приоритетный характер в связи с уменьшением запасов углеводородов $[1,2]$. Повреждения нефтедобывающих конструкций и опасность разлива углеводородов в океан, как это было в Мексиканском заливе [3] и Северном море [4], многократно увеличивают интерес исследователей к изучению способов ликвидации утечек. В случаях таких разливов углеводороды распространяются в виде затопленной струи [5-8]. Одним из наиболее привлекательных способов устранения утечек является установка купола для сбора и эвакуации углеводородов с целью их дальнейшего использования. Технологическая схема работы купола для сбора углеводородов приводится в работе [9].
В случаях, когда повреждение нефтедобывающей конструкции происходит на больших глубинах Мирового океана, зачастую теплофизические характеристики окружающей среды соответствуют условиям стабильного существования гидрата. В таких случаях пузырьки метана будут превращаться в гидратные частицы [10-13]. Накапливаясь внутри купола, гидратные частицы могут придать ему нежелательную плавучесть, помешав установке. Таким образом, процесс гидратообразования должен быть детально рассмотрен в рамках исследования накопления углеводородов в куполе.

В работе [14] рассмотрена модель работы купола, который исключает накопление гидрата. В работе [15] был рассмотрен процесс установки купола для ликвидации нефтегазовых утечек на дне океана при условии, что процесс гидратообразова- 
ния лимитируется диффузией. Это является одним из предельных режимов, принятых для описания гидратообразования. Другим предельным случаем является описание гидратообразования с помощью схемы теплообмена, которая более подробно рассматривается в этой работе. Согласно исследованиям, приведенным в работе [16], было выявлено, что образование гидрата в случае, когда гидратообразование, лимитируется теплообменом с окружающей средой, протекает быстрее, чем в случае диффузионного переноса газа через гидратную оболочку. Вследствие этого газовый пузырек полностью успевает превратиться в гидратную частицу. Процесс гидратообразования начинается, когда пузырек поднялся выше $h^{*}$. Композитными пузырьками будем называть такие пузырьки метана, на поверхности которых уже начала образовываться гидратная оболочка, но полного превращения в гидратную частицу ещё не произошло. В процессе миграции в струе плотность композитного (газ+гидрат) пузырька увеличивается от плотности газа до плотности гидрата. Плотность композитного пузырька становится больше плотности нефти $\rho_{\text {сом }}>\rho_{0}$ на высоте $h_{2}^{*}$.

\section{Постановка задачи}

Будем полагать, что газ, нефть и композитные пузырьки, поступающие внутрь купола из струи [17-21], естественным образом сепарируются внутри купола и образуют соответствующие слои: газа, нефти и гидрата. Расслоение поступающих из струи углеводородов будет происходить согласно плотностям компонентов (рис. 1).

Пусть координаты $z_{o h}$ и $z_{h w}$ соответствуют границам нефть-гидрат и гидрат-вода. Будем полагать, что вначале слой гидрата будет накапливаться ниже слоя нефти до тех пор, пока выполняются условия $\rho_{\text {com }}>\rho_{0}$ и $z_{h w} \geq h_{2}^{*}$, а при $z_{h w}<h_{2}^{*}$ слой гидрата будет накапливаться выше слоя нефти, т. к. $\rho_{\text {сот }}<\rho_{0}$. Вследствие этого поступающие из струи углеводороды расслаиваются внутри купола в следующем порядке (сверху вниз): газ; композитные пузырьки, плотность которых меньше плотности нефти; нефть; композитные пузырьки, плотность которых больше плотности нефти.

Пусть индекс $\left(h_{1}\right)$ относится к слою гидрата, образованного композитными пузырьками, плотность которых больше плотности нефти $\rho_{\text {com }}>\rho_{o}$; индекс $\left(h_{2}\right)$ относится к слою гидрата, образованного композитными пузырьками, плотность которых меньше плотности нефти $\rho_{\text {сот }}<\rho_{0}$. Вследствие этого поступающие из струи углеводороды расслаиваются внутри купола в следующем порядке (сверху вниз): газ - на участке $z_{g h_{2}}<z<z_{n}$, гидрат (образованный композитными пузырьками меньшей плотности) - на участке $z_{g h_{2}}<z<z_{h_{2} 0}$, нефть - на участке $z_{h_{2} 0}<z<z_{\text {oh }}$, гидрат (образованный композитными пузырьками большей плотности) - на участке $z_{o h_{1}}<z<z_{h_{1} w}$.

\section{Основные уравнения}

Законы сохранения масс для углеводородов, поступающих из струи (газ и нефть), запишутся в следующем виде:

$$
\begin{aligned}
& \frac{d M_{g}}{d t}=m_{g}^{+}-m_{g}^{-}, \quad \frac{d M_{o}}{d t}=m_{o}^{+}-m_{o}^{-}, \\
& m_{g}^{+}=\rho_{g} Q_{g}^{e}, \quad m_{o}^{+}=\rho_{o} Q_{o}^{e}, \\
& m_{g}^{-}=\left\{\begin{array}{l}
0, t<t^{*} \\
\rho_{g} Q_{g}^{e}, t \geq t^{*}
\end{array}, \quad m_{o}^{-}=\left\{\begin{array}{l}
0, t<t^{*} \\
\rho_{o} Q_{o}^{e}, t \geq t^{*}
\end{array},\right.\right.
\end{aligned}
$$

здесь $M_{i}, Q_{i}$ - масса и объемный расход $i$-го компонента в куполе; $m_{i}^{+}, m_{i}^{-}$- массовые расходы $i$-го компонента, поступающего и откачиваемого из купола; $t^{*}$ - время начала откачивания углеводородов из купола. Нижние индексы $i=(g, o)$ относятся к газу и нефти, верхние индексы + и - относятся к «поступающему» и «откачиваемому» компоненту.

Законы сохранения масс для слоев композитных пузырьков запишутся в следующем виде:

$$
\begin{aligned}
& \frac{d M_{h_{1}}}{d t}=m_{h_{1}}^{+}, \quad \frac{d M_{h_{2}}}{d t}=m_{h_{2}}^{+}, \\
& \left\{\begin{array}{l}
m_{h_{1}}^{+}=\rho_{\text {com }} Q_{g}, \rho_{c o m}>\rho_{o} \\
m_{h_{1}}^{+}=0, \rho_{\text {com }}<\rho_{o}
\end{array},\right. \\
& \left\{\begin{array}{l}
m_{h_{2}}^{+}=\rho_{\text {com }} Q_{g}, \rho_{\text {com }}<\rho_{o} \\
m_{h_{2}}^{+}=0, \rho_{\text {com }}>\rho_{o}
\end{array},\right.
\end{aligned}
$$

здесь $m_{h_{1}}, m_{h_{2}}^{+}$- массовые расходы композитных пузырьков, поступающих в контрольный объем (КО). Согласно оценкам, приведенным в работе [22], разложением гидрата можно пренебречь.

При сепарации поступающей из скважины смеси с течением времени в куполе возникают области, насыщенные газом, гидратом (образованным композитными пузырьками меньшей плотности), нефтью, гидратом (образованным композитными пузырьками большей плотности) и водой. Соответственно, масса данных продуктов в куполе определяется выражениями:

$$
\begin{gathered}
M_{g}=\int_{z_{g h_{2}}}^{z_{n}} \rho_{g} S_{d}(z) d z, \quad M_{h_{2}}=\int_{z_{h_{2} 0}}^{z_{g h_{2}}} \rho_{h} S_{d}(z) d z, \\
M_{o}=\int_{z_{o h_{1}}}^{z_{h_{2} o}} \rho_{o} S_{d}(z) d z, \\
M_{h_{1}}=\int_{z_{h_{1} w}}^{z_{o h_{1}}} \rho_{h} S_{d}(z) d z, \quad M_{w}=\int_{z_{0}}^{z_{h_{1} w}} \rho_{w} S_{d}(z) d z,
\end{gathered}
$$

где $\rho_{i}$ - плотность $i$-й фазы; $S_{d}(z)$ - площадь сечения купола; нижние индексы $i=(g, h, 0, w)$ относятся соответственно к газу, гидрату, нефти и воде.

Законы сохранения энергии для слоев нефти и газа запишутся в следующем виде:

$$
\begin{gathered}
\frac{d U_{o}}{d t}=-S_{d} q_{o h_{1}}-S_{d} q_{h_{2} o}+c_{o} m_{o}^{+} T_{o}^{+}-c_{o} m_{o}^{-} T_{o}, \\
U_{o}=c_{o} M_{o} T_{o},
\end{gathered}
$$




$$
\frac{d U_{g}}{d t}=-S_{d} q_{g h_{2}}+c_{g} m_{g}^{+} T_{g}^{+}-c_{g} m_{g}^{-} T_{g}, U_{g}=c_{g} M_{g} T_{g}
$$

здесь $q_{o h_{1}}, q_{h_{2}}, q_{g h_{2}}$ - тепловые потоки между слоями нефти и гидрата, гидрата и нефти, газа и гидрата; $T_{o}^{+}$и $T_{g}^{+}-$температуры нефти и газа, поступающие в соответствующие слои из струи.

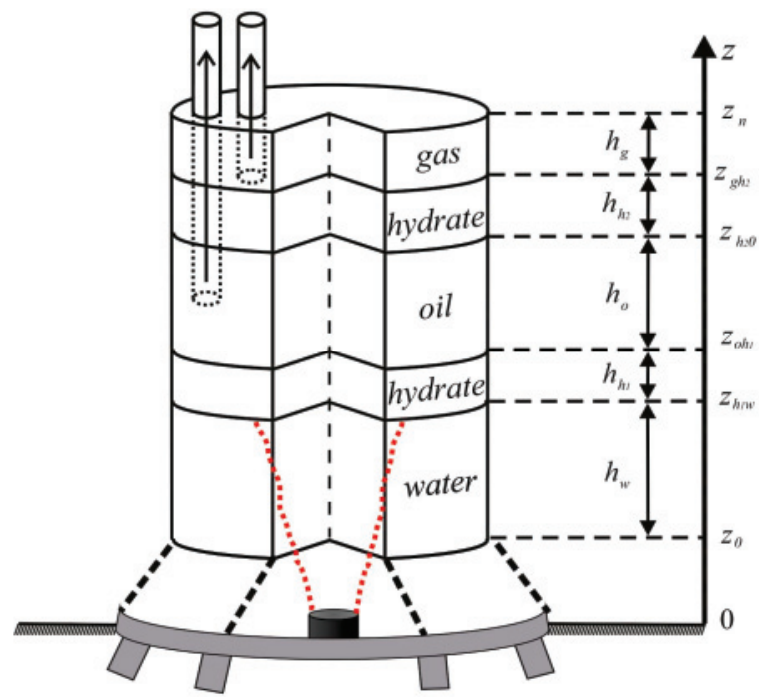

Рис.1. Схела купола и распределения колпонентов внутри ку пола для случая глубоководья при гидратообразовании,

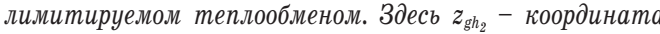
раздела слоев газа и гидрата; $z_{h_{20}}$ - координата раздела слоев гидрата и нефти; $z_{\text {о }}-$ - координата раздела слоев нефти и гидрата; $z_{h_{1} w}$ - координата раздела слоев гидра та и воды; $z_{n}$ и $z_{0}$ соответствуют верхнему и нижнему основанию купола; $h_{g}, h_{0}, h_{w}-$ толщины слоев газа, нефти и воды. Красная пунктирная линия соответствует схематичному обозначению струи

Fig. 1. Scheme of the dome and distribution of components inside the dome for the case of deep water in hydrate formation, $l i$ mited by heat exchange. Here $z_{g h_{2}}$ is the coordinate section of the layers of gas and hydrate; $z_{h_{2}}$ is the coordinate section of the layers of hydrate and oil; $z_{h_{1} w}$ is the coordinate section of the layers of hydrate and water; $z_{n}$ and $z_{0}$ correspond to the upper and lower base of the dome; $h_{g}, h_{0}, h_{w}$ is the thickness of the layers of gas, oil and water. The red dotted line corresponds to the schematic designation of the jet

Тепловой поток между слоями нефти и гидрата $q_{o h_{1}}$ определим, используя выражение для теплообмена для полуограниченного тела согласно [23]:

$$
q_{o h_{1}}=\frac{\lambda_{o}}{\sqrt{\pi \kappa_{o} \tau_{o}}}\left(T_{o}-T_{h s}\right),
$$

здесь $\lambda_{0}-$ коэффициент теплопроводности нефти; $\kappa_{0}=\lambda_{0} / \rho_{0} c_{0}-$ коэффициент температуропроводности нефти; $\tau_{0}$ - время, которое соответствует началу накопления слоя нефти.

Тепловые потоки между слоями гидрата и нефти $q_{h_{2} 0}$ и газа и гидрата $q_{g h_{2}}$ определим, используя выражение для теплообмена для полуограниченного тела согласно [23]:

$$
q_{h_{2} o}=\frac{\lambda_{o}}{\sqrt{\pi \kappa_{o} \tau_{h_{2}}}}\left(T_{o}-T_{h s}\right), q_{g h_{2}}=\frac{\lambda_{g}}{\sqrt{\pi \kappa_{g} \tau_{g}}}\left(T_{g}-T_{h s}\right),(7)
$$

здесь $\lambda_{g}-$ коэффициент теплопроводности газа; $\kappa_{g}=\lambda_{g} / \rho_{g} c_{g}-$ коэффициент температуропроводности газа; $\tau_{g}$ и $\tau_{h_{2}}-$ время, которое соответствует началу накопления слоя газа и слоя композитных пузырьков, располагающегося между слоями газа и нефти.

Для удобства численных расчетов приведем уравнения (1), (2), (4), (5) к следующему виду:

$$
\begin{aligned}
& \frac{d M_{g}}{d t}=\left\{\begin{array}{l}
\rho_{g} Q_{g}^{e}, t<t^{*} \\
0, t \geq t^{*}
\end{array}, \quad \frac{d M_{o}}{d t}=\left\{\begin{array}{l}
\rho_{o} Q_{o}^{e}, t<t^{*} \\
0, t \geq t^{*}
\end{array},\right.\right. \\
& \frac{d M_{h_{1}}}{d t}=\left\{\begin{array}{l}
\rho_{\text {com }} Q_{g}, \rho_{\text {com }}>\rho_{o} \\
0, \rho_{\text {com }}<\rho_{o}
\end{array},\right. \\
& \frac{d M_{h_{2}}}{d t}=\left\{\begin{array}{l}
\rho_{\text {com }} Q_{g}, \rho_{\text {com }}<\rho_{o} \\
0 \rho_{\text {com }}>\rho_{o}
\end{array},\right. \\
& \frac{d T_{o}}{d t}=\frac{1}{c_{o} M_{o}}\left[-S_{d} q_{o h_{1}}-S_{d} q_{o h_{2}}+c_{o} m_{o}^{+}\left(T_{o}^{+}-T_{o}\right)\right], \\
& \frac{d T_{g}}{d t}=\frac{1}{c_{g} M_{g}}\left[-S_{d} q_{g h_{2}}+c_{g} m_{g}^{+}\left(T_{g}^{+}-T_{g}\right)\right] .
\end{aligned}
$$

Начальные условия:

$$
\begin{gathered}
Q_{g}^{+}=Q_{g}^{e}, \quad Q_{g}^{-}=Q_{g}^{e}, Q_{o}^{+}=Q_{0}^{e}, \quad Q_{0}^{-}=Q_{0}^{e}, S_{d}=\pi R^{2}, \\
T_{o}^{+}=T\left(z_{h_{1} w}\right), \quad T_{g}^{+}=T\left(\mathrm{z}_{h_{1} w}\right) .
\end{gathered}
$$

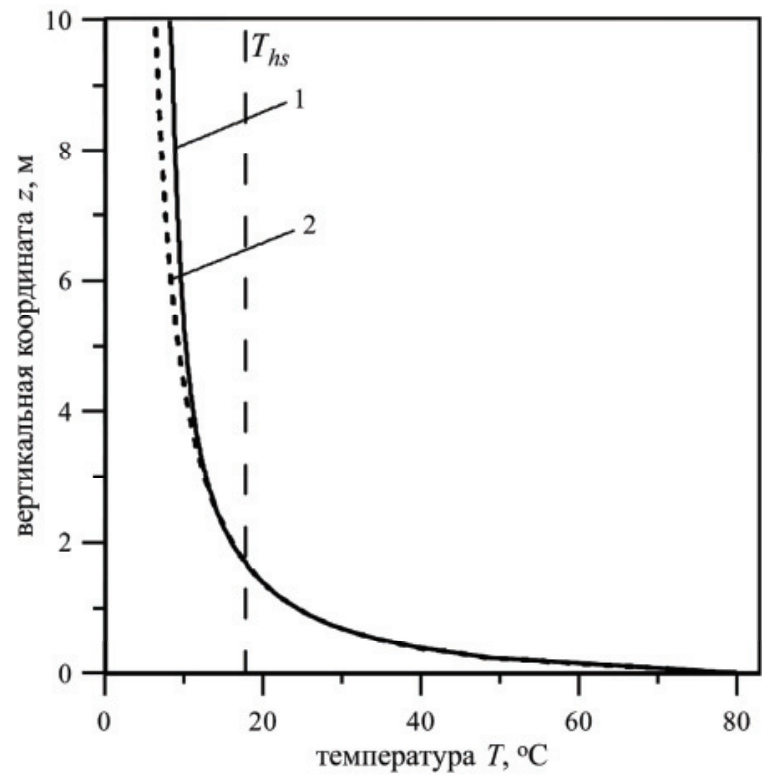

Pис. 2. Зависилость телпературы контрольного объема от вертикальной координаты в случае, когда гидратообразование лимитируется теплообменом (1) и диффузией (2), вертикальная линия соответствует равновесной телпературе гидратообразования [16]. При расчетах используел кривую 1

Fig. 2. Dependence of the control volume $(\mathrm{CV})$ temperature on vertical coordinate in the case when hydrate formation is limited by heat exchange (1) and diffusion (2), the vertical line corresponds to the equilibrium temperature of hydrate formation [16]. When calculating, use curve 1 


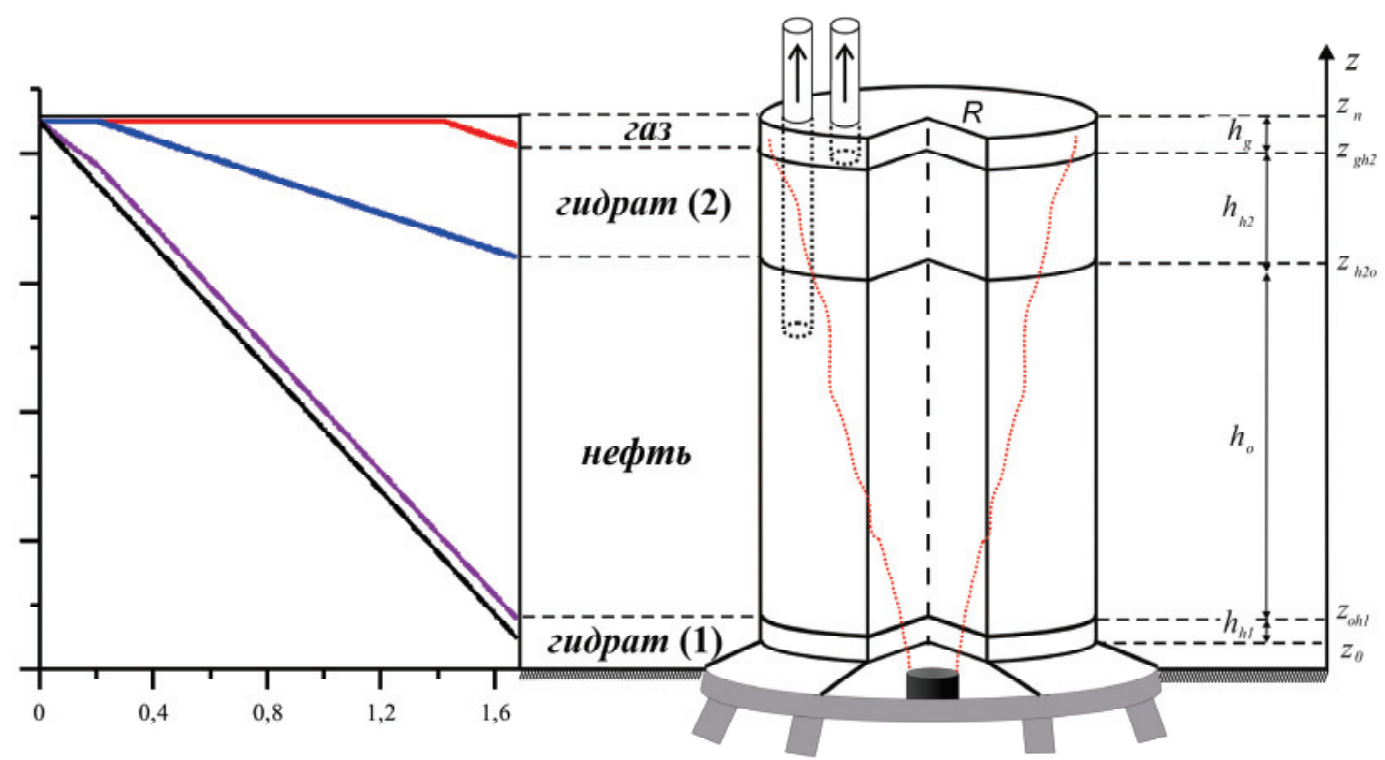

Рис. 3. Зависимость координат, разделяющих слои углеводородов внутри купола, от времени

Fig. 3. Time dependence of the coordinates separating the hydrocarbon layers inside the dome

Зависимость температуры струи от вертикальной координаты была определена в работе [16] и приведена на рис. 3 . Для определения температур $T_{o}^{+}$и $T_{g}^{+}$используем известную температуру струи на высоте, соответствующей координате раздела слоев композитных пузырьков и воды $z_{h, w}$. Из уравнения (8) с учетом (3) следуют уравнения для определения координат $z_{g h_{2}}, z_{h_{2},}, z_{o h_{1}}, z_{h_{1} w}$. Уравнения (8)-(10) с учетом (6), (7) и начальных условий решаются численно, методом Эйлера.

\section{Результаты расчетов}

Параметры системы, которые использовались для расчетов: размеры купола $R=2 \mathrm{м}, H=8 \mathrm{м}$, координата нижнего основания купола $z_{0}=0,5 \mathrm{M}, r=0,1 \mathrm{M}$, $Q_{0}^{e}=0,7 \mathrm{~m}^{3} /$ с и $Q_{g}^{e}=0,3 \mathrm{~m}^{3} / \mathrm{c}, \quad T_{w}=4{ }^{\circ} \mathrm{C}, T^{e}=80{ }^{\circ} \mathrm{C}$, $p=15$ МПа, $c_{0}=2090$ Дж/(кг.К), $c_{g}=2365$ Дж $/(\kappa г \cdot К)$, $c_{h}=2100$ Дж/(кг.К),$c_{w}=4200$ Дж / $($ кг К К $)$, $\rho_{w}=1030 \mathrm{\kappa} / \mathrm{M}^{3}, \quad \rho_{o}=650 \mathrm{\kappa} / \mathrm{M}^{3}, \quad \rho_{g}=99,25 \kappa \Gamma / \mathrm{M}^{3}$, $\rho_{h}=910 \mathrm{\kappa \Gamma} / \mathrm{M}^{3}, \lambda_{w}=0,58$ Вт/(м.К), $\lambda_{g}=0,45$ Вт/(м.К), $\lambda_{0}=0,12$ Вт $/(\mathrm{м} \cdot \mathrm{K}), \mu_{w}=1,57 \cdot 10^{-3}$ Па.c, $L=5 \cdot 10^{5}$ Дж/кг.

На рис. 3 представлена зависимость координат, разделяющих слои углеводородов внутри купола от времени. Видно, что с течением времени координаты раздела соответствующих слоев убывают, что связано с процессом накопления газа, композитных пузырьков и нефти в куполе. Процесс продолжается до полного заполнения купола углеводородами. Внутри купола появились две области, в которых накоплен гидрат. Каждая область насыщенна композитными пузырьками соответствующей плотности.

На рис. 4 представлены зависимости толщин слоев нефти, газа и гидрата от вертикальной координаты. Наибольшая толщина накоплена у слоя нефти, что связано с начальным значением объемного расхода поступающей из скважины нефти.
Вследствие гидратообразования на поверхности пузырьков и заполнения купола сверху вниз сначала накапливается слой композитных пузырьков с плотностью $\rho_{\text {сом }}>\rho_{o}$, затем плотность пузырьков становится меньше и накапливаются композитные пузырьки с плотностью $\rho_{\text {соm }}<\rho_{0}$, после чего начинает накапливаться газ.

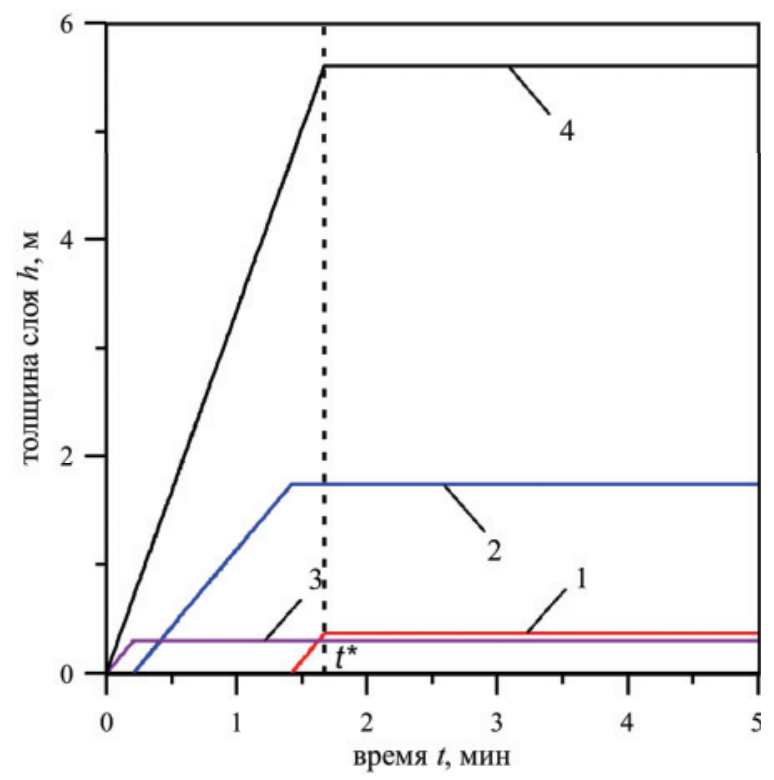

Рис.4. Зависилость толщин слоев в куполе, $t^{*}$ - время начала откачивания углеводородов из купола. Цифрали обозначены: 1 - газ, 2- гидрат между слоями газа и нефти, 3 гидрат между слоями нефти и воды, 4- нефть

Fig. 4. Dependence of the thickness of the layers in the dome. The figures are: 1 - gas, 2 - hydrate between the layers of gas and oil, 3 - hydrate between the layers of oil and water, 4 - oil

На рис. 5 представлена зависимость температур слоев нефти (1), газа (2) и равновесная темпера- 


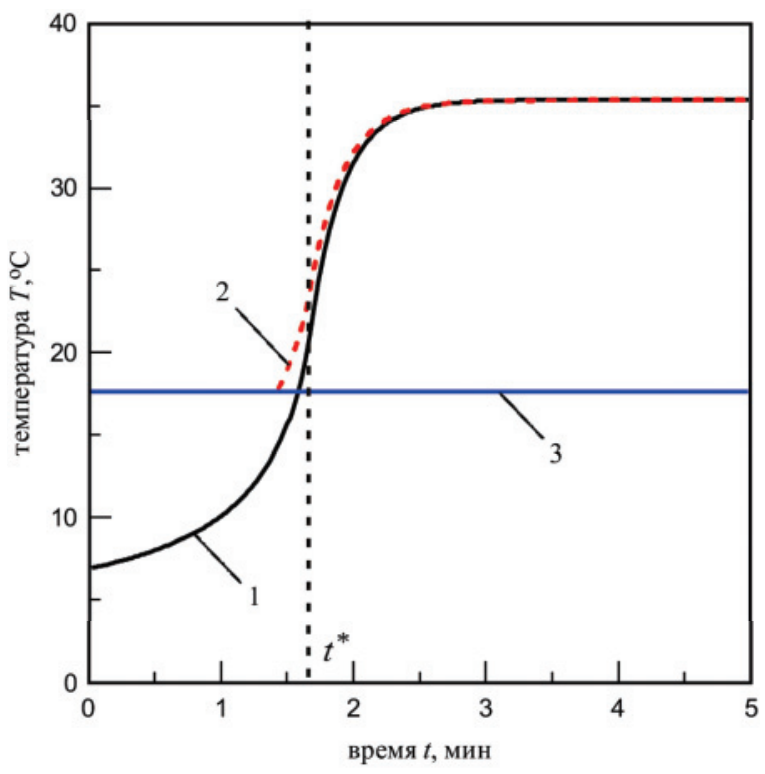

тура гидратообразования (3) от времени для этапа накопления углеводородов в куполе. С течением времени температура слоя нефти возрастает и стремится $\kappa$ температуре поступающих из струи капель нефти. Температура слоя газа также стремится к температуре поступающих из струи пузырьков газа. С течением времени температуры слоев газа и нефти стремятся $\mathrm{\kappa}$ температуре поступающих из струи нефти и газа $T=35,5{ }^{\circ} \mathrm{C}$.

\section{СПИСОК ЛИТЕРАТУРЫ}

1. Хасанов М.К. Численное моделирование закачки углекислого газа в истощенное месторождение углеводородов // Известия Томского политехнического университета. Инжиниринг георесурсов. - 2017. - Т. 328. - № 8. - С. 48-54.

2. Полетаев А.В., Полетаева Е.В. Оценка объемов углеводородных газов газогидратов Азербайджанского сектора Южного Каспия по сейсмическим данным // Известия Томского политехнического университета. Инжиниринг георесурсов. 2018. - T. 329. - № 10. - С. 153-162.

3. Богоявленский В.И., Баринов П.С., Богоявленский И.В. Катастрофа в мексиканском заливе на месторождении Ixtoc комплекса Cantarell // Бурение и нефть. - 2018. - № 1. - С. 3-13.

4. Зайцев В.И., Карпиков А.В. Средства борьбы с нефтяными загрязнениями на шельфе Северных морей / / Вестник Иркутского государственного технического университета. - 2015. № 6 (101). - C. 48-52.

5. Chen F.H., Yapa P.D. A model for simulating deepwater oil and gas blowouts part ii: comparison of numerical simulations with deepspill field experiments // Journal of Hydraulic Research. 2003. - V. 41. - № 4. - P. 353-365.

6. Lee J.H.W., Chu V.H. Turbulent jets and plumes - a Lagrangian approach. - Kluwer, 2003. - 390 p.

7. Bishnoi P.R., Maini B.B. Laboratory study of behaviour of oil and gas particles in salt water, relating to deepwater blowouts / / Spill Technology Newsletter. - 1979. - V. 4. - № 1. - P. 24-36.

8. Кильдибаева С.Р., Гималтдинов И.К. Динамика многофазной затопленной струи с учетом образования гидратов // Вестник Тюменского государственного университета. Физико-математическое моделирование. Нефть, газ, энергетика. - 2015. T. 1. - № 3. - C. 92-101.
Puc. 5. Зависимость температур слоев нефти (1), газа (2) и равновесной температуры гидратообразования (3) от времени, $t^{*}=1,67$ мин

Fig. 5. Dependence of the temperatures of the layers of oil (1) gas (2) and the equilibrium temperature of hydrate formation (3) on time $t^{*}=1,67 \mathrm{~min}$

\section{Заключение}

Рассмотрен процесс накопления углеводородов в куполе для случая, когда гидратообразование на поверхности пузырьков метана описывается схемой теплообмена. Когда плотность композитных пузырьков больше плотности нефти, слой гидрата (образованного композитными пузырьками) накапливается между слоями нефти и воды, в случае, когда плотность пузырька меньше плотности нефти, слой гидрата (образованного композитными пузырьками) накапливается между слоями газа и нефти. В результате расчетов определены температурные значения углеводородов, которые накапливаются внутри купола. Установлено, что с течением времени температуры слоев газа и нефти стремятся $\kappa$ температуре поступающих из струи углеводородов.

Работа выполнена при поддержке гранта Российского фонда фундаментальных исследований (грант № 18-31-00264_мол_а).

9. Carte G.A. Novel concept to control and remediate deep water oil spills: the universal deepwater oil containment system (UDOC). URL: https://www.yumpu.com/en/document/read/3649822/ universal-deepwater-oil-containment-george-carter-inventions (дата обращения 26.03.2018).

10. Migration of a single gas bubble in water during the formation of stable gas-hydrate crust on its surface / V.S. Shagapov, A.S. Chiglintseva, A.A. Rusinov, B.I. Tazetdinov // Theoretical Foundations of Chemical Engineering. - 2017. - V. 51. - № 2. - P. 216-223.

11. Shagapov V.Sh., Chiglintseva A.S., Rusinov A.A. Bubble Migration during Hydrate Formation // Journal of Applied Mechanics and Technical Physics. - 2015. - V. 56. - № 2. - P. 202-210.

12. Chen F.H., Yapa P.D. Estimating hydrate formation and decomposition of gases released in a deepwater ocean plume // Journal of marine systems. - 2001. - № 30. - P. 21-32.

13. Sloan E.D. Clathrate hydrates of natural gases. $2^{\mathrm{d}}$ ed. - New York, Mercel dekker, Inc., 1997. - 750 p.

14. Gimaltdinov I.K., Kildibaeva S.R. About the theory of initial stage of oil accumulation in a dome-separator // Thermophysics and Aeromechanics. - 2015. - V. 22. - № 3. - C. 387-392.

15. Gimaltdinov I.K., Kildibaeva S.R. Model of a submerged jet accounting for two limiting schemes of hydrate formation // Thermophysics and Aeromechanics. - 2018. - V. 25. - № 1. P. $75-83$.

16. Gimaltdinov I.K., Kildibaeva S.R. On the theory of accumulation of hydrocarbons in a dome used to eliminate a technogenic spill at the bottom of the ocean // Journal of Engineering Physics and Thermophysics. - 2018. - V. 91. - № 1. - P. 246-251.

17. Davidson M.J., Pun K.L. Weakly advected jets in crossflow // Journal of hydraulic research. - 1999. - V. 125. - № 1. P. 47-58. 
18. Socolofsky S.A., Adams E.E. Multi-phase plumes in uniform and stratified crossflow // Journal of hydraulic research. - 2002. V. 40. - № 6. - P. 661-672.

19. Pun K.L., Davidson M.J. On the behavior of advected plumes and thermals // Journal of hydraulic research. -1999. - V. 37. № 4. - P. 519-540.

20. Zheng L., Yapa P.D. Simulation of oil spills from underwater accidents II: Model verification // Journal of hydraulic research. 1998. - V. 36. - № 1. - P. 117-134.
21. Zheng L., Yapa P.D., Chen F. A model for simulating deepwater oil and gas blowouts. P. I: theory and model formulation // Journal of hydraulic research. - 2002. - V. 41. - № 4. - P. 339-351.

22. Насыров А.А. Моделирование процесса наполнения «куполасепаратора», предназначенного для ликвидации нефтегазовых выбросов в зоне морского дна // Вестник Кемеровского государственного университета. - 2015. - № 2-1 (62). - С. 41-45.

23. Лыков А.В. Теория теплопроводности. - М.: Высшая школа, 1967. -600 c.

Поступила 17.12.2018 2.

\section{Информация об авторах}

Кильдибаева C.P., кандидат физико-математических наук, доцент кафедры прикладной информатики и программирования Стерлитамакского филиала Башкирского государственного университета.

Гималтдинов И.К., доктор физико-математических наук, профессор кафедры физики Уфимского государственного нефтяного технического университета. 


\title{
THEORETICAL MODEL FOR HYDROCARBON ACCUMULATION IN A DOME TAKING INTO ACCOUNT CONDENSATION, LIMITED BY HEAT TRANSFER
}

\author{
Svetlana R. Kildibaeva', \\ freya.13@mail.ru \\ llyas K. Gimaltdinov², \\ iljas_g@mail.ru \\ 1 Sterlitamak Branch of Bashkir State University, \\ 49, Lenin Avenue, Sterlitamak, 453100, Russia. \\ 2 Ufa State Oil Technical University, \\ 1, Cosmonavtov street, Ufa, 450062, Russia.
}

The relevance of the research is related to the increase in the scale of hydrocarbon production in the offshore zone of the world ocean and the associated risks of accidental spills of hydrocarbons. In this regard, it is necessary to study the mathematical model of the dome, designed to eliminate deep-sea leaks. According to the formulation of the problem, the thermophysical characteristics of the environment correspond to the conditions of stable existence of hydrate. To describe hydrate formation on the surface of methane bubbles, a limit scheme is proposed, according to which hydrate formation is limited by heat exchange. In earlier works, the accumulation of hydrocarbons was considered, taking into account the hydrate formation limited by diffusion, which is another limiting case of describing hydrate formation.

The main aim of the research is to study the features of hydrocarbon accumulation (oil, gas, hydrate) in the dome for the case when hydrate formation is limited by heat exchange with the environment.

Object of research is a stream of hydrocarbons consisting of water, oil droplets, gas bubbles and composite bubbles, which leads to the accumulation of hydrocarbons in the dome when gets into it. The thermophysical characteristics of the environment correspond to the conditions of stable existence of hydrate.

Methods. The mathematical model of hydrocarbon accumulation in the dome is constructed. For describing heat and mass transfer the authors have used the system of equations that includes conservation laws for mass of gas, oil and hydrate, equation of energy conservation for the layers of gas and oil, as well as auxiliary equations for calculating heat flows.

Result. The paper considers the process of hydrocarbon accumulation in the dome in the case when hydrate formation on the surface of methane bubbles is limited by heat exchange. When the density of the composite bubbles greater than the that of oil, a layer of hydrate (formed composite bubbles) is accumulated between the layers of oil and water; in the case when the density of the bubble is less than that of oil, a layer of hydrate (formed composite bubbles) is accumulated between the layers of oil and gas. The authors determined the temperature field for hydrocarbons accumulated inside the dome. Over time, the temperature of the layers of gas and oil tend to temperature of oil and gas coming from the jet.

Key words:

Dome, hydrocarbon spill, shelf, oil, hydrate formation.

The research was supported by the grant of the Russian Fund of Fundamental Research (grant no.18-31-00264 мол_a).

\section{REFERENCES}

1. Khasanov M.K. Numerical simulation of carbon dioxide injection into a depleted hydrocarbon field. Bulletin of the Tomsk Poly technic University. Geo assets Engineering, 2017, vol. 328, no. 8, pp. 48-54. In Rus.

2. Poletaev A.V., Poletaeva E.V. Estimation of volumes of hydrocarbon gases of gas hydrates of the Azerbaijan sector of the South Caspian sea by seismic data. Bulletin of the Tomsk Polytechnic University. Geo assets Engineering, 2018, vol. 329, no. 10, pp. 153-162. In Rus.

3. Bogoyavlensky V.I., Barinov P.S., Bogoyavlensky I.V. Disaster in the Gulf of Mexico at the Ixtoc Deposit of the Cantarell complex. Burenie i neft, 2018, no. 1, pp. 3-13. In Rus.

4. Zaytscev V.I., Karpikov A.V. Means of oil pollution control on the shelf of the Northern seas. Vestnik Irkutskogo gosudarstvennogo tekhnicheskogo universiteta, 2015, no. 6 (101), pp. 48-52. In Rus.

5. Chen F.H., Yapa P.D. A model for simulating deepwater oil and gas blowouts part ii: comparison of numerical simulations with deepspill field experiments. Journal of Hydraulic Research, 2003, vol. 41, no. 4, pp. 353-365.

6. Lee J.H.W., Chu V.H. Turbulent jets and plumes - a Lagrangian approach. Kluwer, 2003. 390 p.
7. Bishnoi P.R., Maini B.B. Laboratory study of behaviour of oil and gas particles in salt water, relating to deepwater blowouts. Spill Technology Newsletter, 1979, vol. 4, no. 1, pp. 24-36.

8. Kildibaeva S.R., Gimaltdinov I.K. Dynamics of multiphase submerged jet taking into account hydrate formation. Vestnik Tyumenskogo gosudarstvennogo universiteta. Fiziko-matematicheskoe modelirovanie. Neft, gaz, energetika, 2015, vol. 1, no. 3, pp. 92-101. In Rus.

9. Carte G.A. Novel concept to control and remediate deep water oil spills: the universal deepwater oil containment system (UDOC). URL: https://www.yumpu.com/en/document/read/3649822/ universal-deepwater-oil-containment-george-carter-inventions (accessed: 18 March 2018).

10. Shagapov V.S., Chiglintseva A.S., Rusinov A.A., Tazetdinov B.I. Migration of a single gas bubble in water during the formation of stable gas-hydrate crust on its surface. Theoretical Foundations of Chemical Engineering, 2017, vol. 51, no. 2, pp. 216-223.

11. Shagapov V.Sh., Chiglintseva A.S., Rusinov A.A. Bubble Migration during Hydrate Formation. Journal of Applied Mechanics and Technical Physics, 2015, vol. 56, no. 2, pp. 202-210.

12. Chen F.H., Yapa P.D. Estimating hydrate formation and decomposition of gases released in a deepwater ocean plume. Journal of marine systems, 2001, no. 30, pp. 21-32. 
13. Sloan E.D. Clathrate hydrates of natural gases. $2^{\mathrm{d}}$ ed. New York, Mercel dekker, Inc, $1997.750 \mathrm{p}$.

14. Gimaltdinov I.K., Kildibaeva S.R. About the theory of initial stage of oil accumulation in a dome-separator. Thermophysics and Aeromechanics, 2015, vol. 22, no. 3, pp. 387-392.

15. Gimaltdinov I.K., Kildibaeva S.R. Model of a submerged jet accounting for two limiting schemes of hydrate formation. Ther mophysics and Aeromechanics, 2018, vol. 25, no. 1, pp. 75-83.

16. Gimaltdinov I.K., Kildibaeva S.R. On the theory of accumulation of hydrocarbons in a dome used to eliminate a technogenic spill at the bottom of the ocean. Journal of Engineering Physics and Thermophysics, 2018, vol. 91, no. 1, pp. 246-251.

17. Davidson M.J., Pun K.L. Weakly advected jets in crossflow. Journal of hydraulic research, 1999, vol. 125, no. 1, pp. 47-58.

18. Socolofsky S.A., Adams E.E. Multi-phase plumes in uniform and stratified crossflow. Journal of hydraulic research, 2002, vol. 40, no. 6 , pp. 661-672.
19. Pun K.L., Davidson M.J. On the behavior of advected plumes and thermals. Journal of hydraulic research, 1999, vol. 37, no. 4, pp. 519-540.

20. Zheng L., Yapa P.D. Simulation of oil spills from underwater accidents II: Model verification. Journal of hydraulic research, 1998, vol. 36, no. 1, pp. 117-134.

21. Zheng L., Yapa P.D., Chen F. A model for simulating deepwater oil and gas blowouts - part I: theory and model formulation. Journal of hydraulic research, 2002, vol. 41, no. 4, pp. 339-351.

22. Nasyrov A.A. Modeling of the filling process of the «dome-separator", designed to eliminate oil and gas emissions in the seabed area. Vestnik Kemerovskogo gosudarstvennogo universiteta, 2015, no. 2-1 (62), pp. 41-45. In Rus.

23. Lykov A.V. Teoriya teploprovodnosti [Heat conduction theory]. Moscow, Vysshaya shkola publ., $1967.600 \mathrm{p}$.

Received: 17 December 2018.

\section{Information about the authors}

Svetlana R. Kildibaeva, Cand. Sc., associate professor, Sterlitamak Branch of Bashkir State University.

Ilyas K. Gimaltdinov, Dr. Sc., professor, Ufa State Oil Technical University. 